Research Article

\title{
The effect of Thespesia populnea against Plasmodium falciparum enoyl acyl carrier protein reductase receptor by study in silico
}

\author{
I Made Prasetya Kurniawan ${ }^{1 *}$, Prawesty Diah Utami ${ }^{2}$, Risma ${ }^{3}$ \\ 1) Faculty of Medicine, University of Hang Tuah Surabaya. \\ 2) Parasitology Department, Faculty of Medicine, University of Hang Tuah Surabaya. \\ 3) Parasitology Department, Faculty of Medicine, University of Hang Tuah Surabaya.
}

\section{A R T I C L E I N F O}

$\begin{array}{ll}\text { Submitted } & : 12^{\mathrm{st}} \text { July } 2020 \\ \text { Accepted } & : 03^{\mathrm{st}} \text { February } 2021 \\ \text { Published } & : 25^{\mathrm{st}} \text { July } 2021\end{array}$

Keywords:

Thespesia populnea (L.) Soland ex. Correa, in silico, malaria, Plasmodium falciparum enoyl acyl carrier protein reductase receptor, Baru laut plant

\section{*Correspondence:}

setyapras123@yahoo.com

This is an Open acces article under the CC-BY-NC license

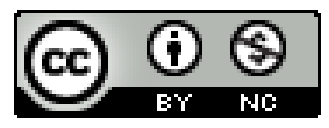

\begin{abstract}
Indonesia is a country that has abundant natural resources; one of them is the Baru laut plant which is the latest breakthrough because it has an active substance that can be used as an anti-malaria medicine. It is very beneficial because there has been a case of resistance of artemisinin derivatives in Indonesia. The purpose of this study was to determine the potential of active compounds in Baru laut plants (Thespesia populnea (L.) Soland ex. Correa) against the Plasmodium falciparum enoyl acyl carrier protein reductase receptor in $P$. falciparum through in silico studies. This research is purely experimental using the One-Shot Experimental Study research design method. Observations were only made once between the variables studied through three analyzes, namely prediction analysis of active compound content, prediction analysis of the mechanism of action of active compound content, and prediction analysis of ADME active compound. The study results show that there are three active compounds in Baru laut plants that have antimalarial potential. The three compounds include gossypol, linoleic acid, and beta-sitosterol, have their respective potential in becoming a malaria drug. This study concludes that Baru laut plants have potential as anti-malaria drugs.
\end{abstract}




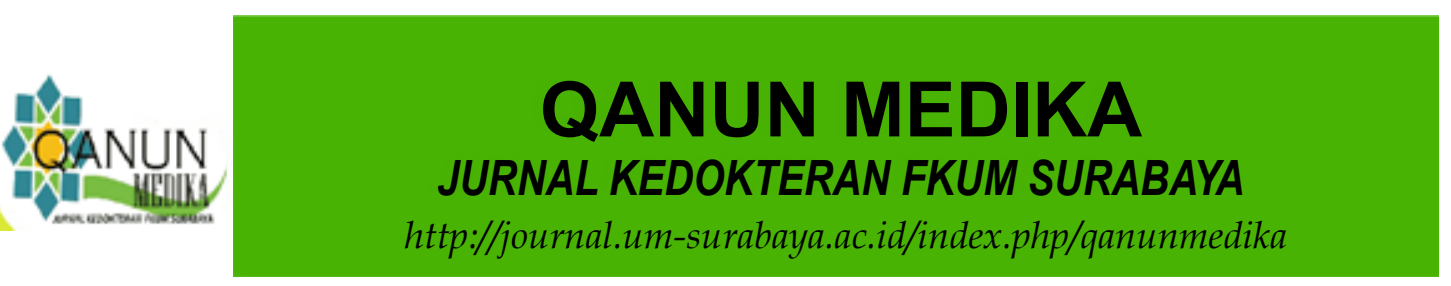

\section{INTRODUCTION}

Based on WHO research in 2019, malaria in the world population showed a figure of 57.4 out of 1000 population while for Africa, the highest-ranking was 229.3 out of 1000 population (World Health Organization, 2019). According to the Indonesian Ministry of Health, the Annual Parasite Incidence (API) in 2015 showed 0.85 of the 1000 population. The distribution within the province from 2015, the provinces with the highest API, is Papua with a value of 31.93 , followed by West Papua with a value of 31.29 and NTT 7.04. However, five provinces in Indonesia have reached the value of 0 out of 1000 population, which means they are free from malaria, namely North Kalimantan, West Java, Banten, East Java, Jakarta, and Bali. Nevertheless, with transportation progress, the risk of malaria transmission from populations originating from endemic areas to non-endemic populations can occur (Kementerian Kesehatan RI, 2016). Furthermore, based on WHO research, in 2018, people at risk of contracting malaria in Indonesia reached 263,991,376 people, and the death rate in Indonesia reached 5110 people in 2017 (World Health Organization, 2018).

The cause of malaria is the Plasmodium parasite transmitted through the bite of a female Anopheles mosquito. Plasmodium parasites that infect humans are divided into five species: Plasmodium falciparum, Plasmodium vivax, Plasmodium malariae, Plasmodium knowlesi, Plasmodium ovale. Plasmodium falciparum is a species of Plasmodium that causes severe clinical manifestations and can cause death if inadequate handling (Putra, 2018). Malaria parasites enter the human body through the bite of female Anopheles mosquitoes; in the circulation of these parasites enter the red blood cells, causing changes in the structure of red blood cells and cause red blood cell rupture (Yunita et al., 2019).

The characteristics of the pathogenesis and pathophysiology between malaria species are different, and this causes different clinical manifestations (Fitriany \& Sabiq, 2015). Plasmodium falciparum has common clinical manifestations such as flu-like symptoms. However, in certain conditions, clinical manifestations of Plasmodium falciparum can develop into fatal complications such as cerebral malaria, severe anemia, acute kidney failure, pulmonary edema, hypoglycemia, shock, spontaneous bleeding, acidosis, and hemoglobinuria. This is because this parasite can infect all red blood cells, both young and old, so that damage to red blood cells or hemolysis occurs more severely than other Plasmodium species (Sutrimah, 2017).

Indonesia is a country that has abundant natural resources, so the consumption of herbal medicines has become a culture for the people of Indonesia. One of them is a Baru laut plant or Thespesia populnea (L.) Soland ex. Correa. The plant has many benefits; one of the properties of the plant is an anti-malaria drug (Yani et al., 2014). The emergence of Plasmodium falciparum resistance to various antimalarial drugs, especially artemisinin, is related to genetic mutations from the parasitic receptor protein (Suwandi, 2015).

Plasmodium falciparum has an enzyme called Plasmodium falciparum Enoyl Acyl Carrier Protein Reductase, or PfENR, located in the apicoplast is an organelle that regulates various metabolic processes in parasitic cells. The enzyme plays a role in the biosynthesis of type II fatty acids which are very much needed in the manufacture of membranes and as a source of energy reserves. The PfENR enzyme's role for $P$. falciparum is crucial because if there is a disruption to the work of the enzyme, the 
biological membrane is not formed, and there is a lack of energy reserves (Zuchrian, 2010).

This in silico test is a test carried out by docking molecules by predicting the activity of compounds in the selected target cell, which will later show results in the form of the amount of energy used from the compound to be docking to the receptors, which will display the bond energy value or Rerank Score (RS). The more negative or smaller the energy needed, the more stable the bonds formed, which means the greater the compound's activity (Kesuma et al., 2018).

Based on this phenomenon, researchers want to explore the effect of active substances in Baru laut plants (Thespesia populnea (L.) Soland ex. Correa) with PfENR receptor on Plasmodium falciparum by a study in silico.

\section{METHODS}

This study uses a One-Shot Experimental Study design to test the potential of active compounds in Baru laut plants (Thespesia populnea (L.) Soland ex. Correa) against the Plasmodium falciparum Enoyl Acyl Carrier Protein Reductase receptor in Plasmodium falciparum. Observations were only made once between the variables examined in this study. This research began in March 2020 until August 2020, which was carried out at the INBIO Lowokwaru Malang Indonesia Biomolecular and Bioinformatics Laboratory with ethical clearance numbers I/003/UHT.KEPK.03/ III/2020.

This research method is in silico which consists of the following steps: preparation of ingredients, prediction of potential compounds, pathway prediction, molecular docking, visualization of docking results, visualization of amino acid interactions, prediction of ADME (absorption, distribution, metabolism, and excretion), and the last prediction of toxicity.

\section{Preparation of ingredients}

Downloading compounds inactive plants were obtained from Dr.Duke PhytoChemical data (https://phytochem.nal.usda.gov/phytochem/ search/list) and the structure of the Plasmodium falciparum Enoyl Acyl Carrier Protein Reductase (PfENR) from the Indonesian INBIO Laboratory database.

\section{Prediction of potential compounds}

The compound that has been obtained will then be analyzed for its potential using WAY2DRUG PASS prediction original version (http:// pharmaexpert.ru/PASSonline/index.php) as an antimalarial. The results of the search were measured using the Probability To Be Active value (the $\mathrm{Pa}$ value is a value that illustrates the potential of a compound being tested) to assess the activity related to the potential of the herb as a Plasmodium inhibitor. Determination of this value is done by comparing the structure of herbal compounds inputted with compounds that have been proven to be antimalarial. $\mathrm{Pa}$ values have two criteria (Filimonov et al., 2014), that is:

- If the Pa value is more than 0.7 , it indicates that the compound is predicted to have high potential as an antiprotozoal (Plasmodium) because it has a high similarity with a compound that has been proven to be an antiprotozoal (Plasmodium).

- Whereas if the $\mathrm{Pa}$ value is more than 0.3 but less than 0.7 , the compound has potential as an antiprotozoal (Plasmodium) but a low similarity with a compound that has been proven to be an antiprotozoal (Plasmodium). 

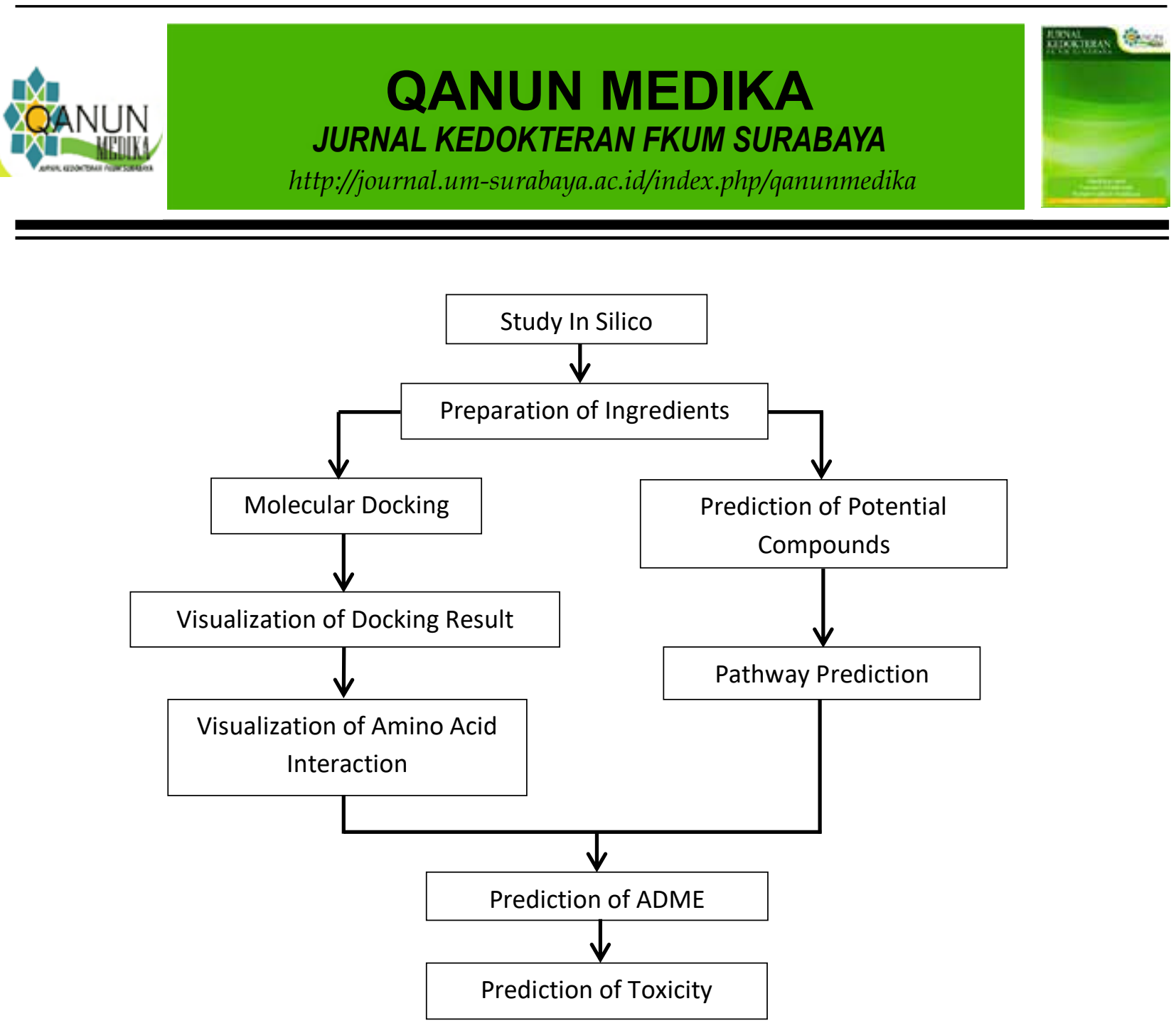

Figure 1. Research work scheme

\section{Pathway prediction}

After searching for bioactivity from herbs, then a pathway prediction is performed using the STITCH DB original version with a maximum prediction of 50 interactions. All herbal compounds were analyzed for their interaction with the target protein using the STITCH DB Version 5.0 original version (http://stitch.embl.de/) webserver with the Plasmodium falciparum organism model and secure medium (Szklarczyk et al., 2016).

\section{Molecular docking}

Molecular docking is done using Autodock Vina's original version in the PyRx 9.5 program. The target protein used is the Crystal structure of Plasmodium falciparum FabI complexed with NAD and inhibitors 7-(4-Chloro-2hydroxyphenoxy)-4-methyl-2H-chromen-2one (PDB 4IGE Chain B). While the ligands used are Beta-Sitosterol, Linonelic Acid,
Artemisinin, Gossypol, and ligand control is 7-(4-chloro-2-hydroxyphenoxy)-4-methyl2H-chromen-2-one. Docking is a specific docking by mimicking the binding bond between the PfENR protein with inhibitor control to predict the strength of the interaction between the receptor and the ligand, based on the value of the binding affinity. The more negative the value, the stronger the interaction that occurs between receptors and ligands. If the bioactive tested has a score close to the control score, it can be predicted that the bioactive can have antagonistic activity against the target protein (Seeliger \& De Groot, 2010). By using the following grid box :

- $\quad$ receptor $=\mathrm{t} 1 . \mathrm{pdbqt}$

- exhaustiveness $=8$

- $\quad$ num modes $=9$

- $\quad$ center_x $=10.8213932702$

- center_y $=99.3895537702$ 
- $\quad$ center_z $=25.471763746$

- $\quad$ size_ $\mathrm{x}=11.709918201$

- $\quad$ size_y $=13.7239389014$

- $\quad$ size_z $=13.6149749039$

- $\mathrm{CPU}=7$

\section{Visualization of docking results}

Visualization of docking result using the PyMol 2.3.1 original version program.

\section{Visualization of amino acid interactions}

Visualization of amino acid interactions using the LigPlot 2.1 original version program.

\section{Prediction of ADME (absorption, distribution, metabolism, and excretion)}

Prediction of ADME using the SWISS ADME webserver original version (http://www. swissadme.ch/index.php). The results of this prediction can be reviewed using the Lipinski parameter. Lipinski's rule of 5 has the following criteria (Ramadhan, 2019):

- Not more than 5 hydrogen bond donors (total bond of nitrogen-hydrogen or oxygenhydrogen).

- Not more than 10 hydrogen bond receptors (all nitrogen or oxygen atoms).

\section{- Molecular weight less than 500 Dalton}

Then do a Blood-brain barrier (BBB) analysis to predict whether the compound can penetrate the blood-brain barrier. Moreover, the analysis of HIA (Human Intestinal Absorption) is a prediction to estimate the number of compounds that can be absorbed by the gastrointestinal (GI). The higher the value of HIA, the more is absorbed (Daina et al., 2017)

\section{Prediction of toxicity}

Prediction of toxicity using Pro-Tox original version (http://tox.charite.de/protox_II/) using the toxic dose or LD50 parameters with values in $\mathrm{mg} / \mathrm{kg}$ body weight. LD50 is the mean lethal dose which means the dose at which $50 \%$ of test subjects die after exposure to the compound. The toxicity class is defined according to the chemical labeling classification system that is the globally harmonized system (GHS). GHS can be classified into (Fallis, 2013).

- Class I : fatal if swallowed (LD50 $\leq 5)$.

- Class II : fatal if swallowed $(5<$ LD50 $\leq$ $50)$.

- Class III : toxic if swallowed $(50<$ LD50 $\leq 300)$.

- Class IV : dangerous if swallowed (300 $<$ LD50 $\leq 2000$ ).

- Class V : may be dangerous if swallowed $(2000<$ LD50 $\leq 5000)$.

- Class VI : non-toxic (LD50> 5000).

\section{RESULTS}

\section{The Content of Active Substances In Baru laut Plants and Prediction of Potential Antiparasitic}

The prediction of potential compounds using WAY2DRUG PASS prediction (http:// pharmaexpert.ru/PASSonline/index.php) is performed. The results of the analysis can be seen in the Table 1.

Table 1 states that Baru laut plants have several active substances, namely betasitosterol, gossypol, and linoleic acid. The potential of Baru laut plant active ingredients as antiparasitic shows that gossypol has no potential as an antiprotozoal, but betasitosterol and linoleic acid have antiparasitic activity. Based on the analysis using Pa values, it is known that there are two other compounds in Thespesia populnea (beta-sitosterol and linoleic-acid) that have an antiprotozoal role (Pa value $<0.3$ ), but the value is not as high as artemisinin $(\mathrm{Pa}$ value $=0.954)$. 


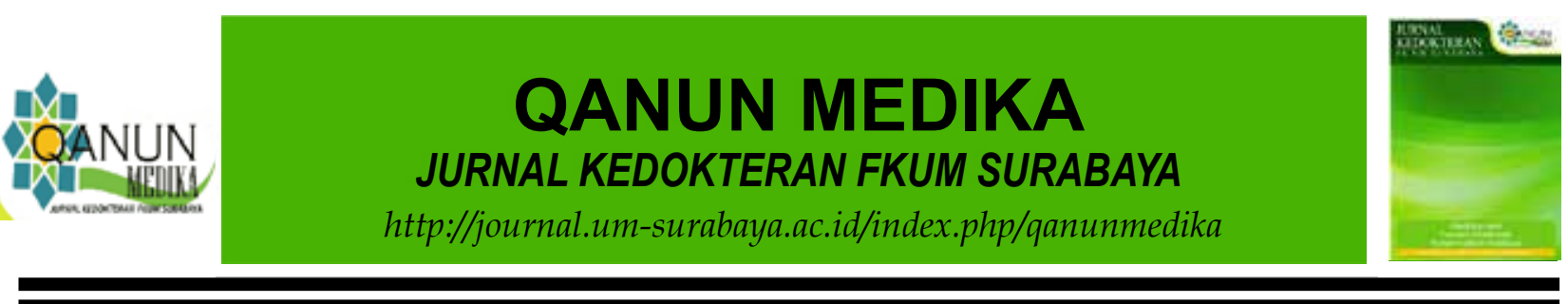

Table 1. Result of prediction of potential compounds.

\begin{tabular}{clcc}
\hline No & Substances & Antiprotozoal (Plasmodium) & Antiparasitic \\
\hline 1 & Beta-sitosterol & 0.159 & Not found \\
2 & Gossypol & Not found & 0.382 \\
3 & Linoleic-acid & 0.172 & 0.388 \\
4 & Artemisinin & 0.954 & 0.857 \\
\hline
\end{tabular}
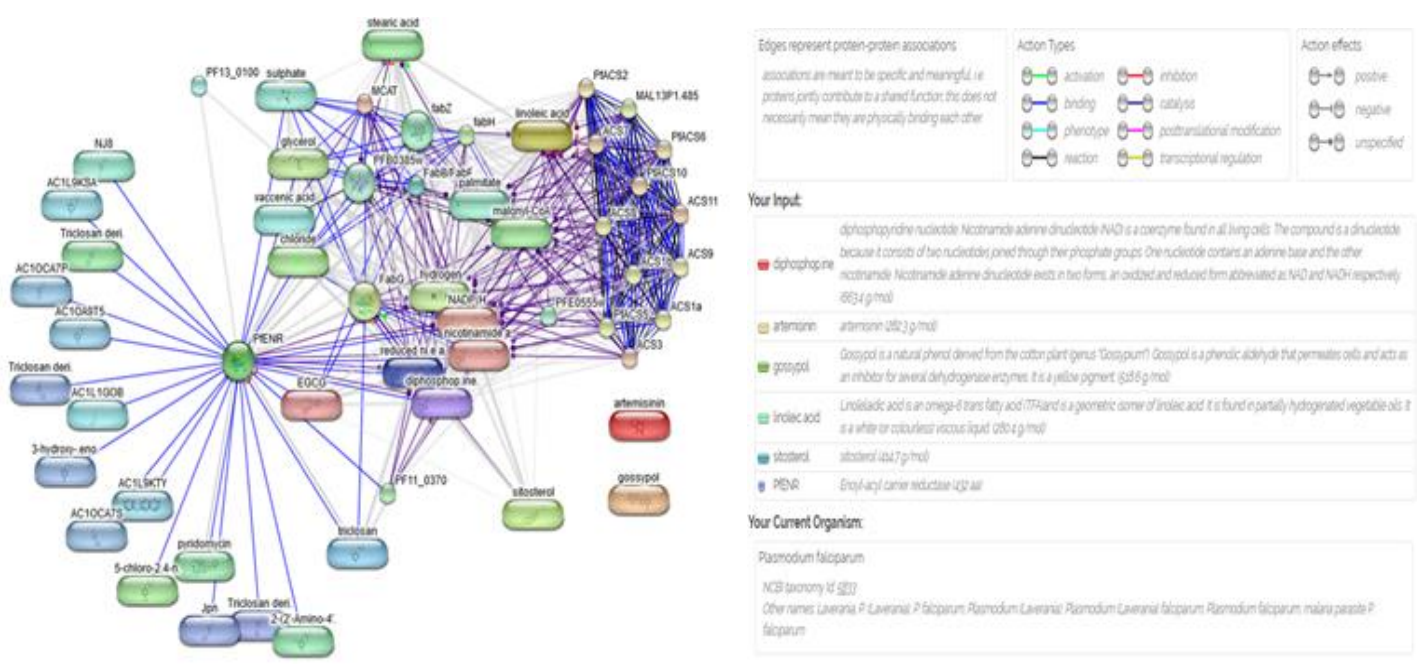

Figure 2. Pathway Prediction active compounds of Baru laut plant against PfENR

\section{Prediction of the Mechanism of Action of Active Compounds Against Pfenr}

Analysis of the prediction of active substances' mechanism of action using the STITCH DB program with a maximum prediction of 50 interactions. The prediction results are in the Figure 2, where it shows no direct interaction between the active compounds of Baru laut plants and artemisinin against PfENR.

The interaction between the active substances of Baru laut plants with PfENR can be seen in the Figure 3. There appears to be an indirect interaction between the active compounds of Baru laut plants, beta-sitosterol, and linoleicacid in diphosphopyridine nucleotide, or another name, nicotinamide adenine dinucleotide (NAD) in PfENR. Furthermore, the active ingredients gossypol and artemisinin have no direct or indirect interaction with PfENR.

Analysis of the prediction of the mechanism of action of active Baru laut substances against PfENR using the molecular docking approach was also carried out in this study. Molecular docking results and visualization images can be seen in the Table 2 and Figure 4.

Binding affinity describes the ability of an active compound as a ligand to bind to its receptors. If the binding value of affinity is getting smaller (the more negative), the affinity between the receptor and the ligand is greater. Hydrogen bonds significantly influence the affinity of ligands and receptors because they have higher energy than hydrophobic bonds (1-7 times greater) (Fitriah, 2017). Based on the results of docking of several active compounds compared to the artemisinin derivate above, it can be said that beta-sitosterol has the greatest affinity bond compared to controls and other compounds. The active linoleic-acid compound has the weakest affinity for PfENR. The results of twodimensional ligplot visualization to determine the hydrogen and hydrophobic bonds of active 


\section{QANUN MEDIKA \\ JURNAL KEDOKTERAN FKUM SURABAYA \\ http://journal.um-surabaya.ac.id/index.php/qanunmedika}

compounds with receptors and compared with controls can be seen in the Table 3 .

The above results show that the active compound beta-sitosterol forms nine hydrophobic bonds at the same amino acid residue with comparison controls. Gossypol forms one hydrogen bond and five hydrophobic bonds, and linoleic acid forms seven hydrophobic bonds without forming hydrogen bonds. If the data analysis of ligplot visualization combined with the prediction of binding affinity of active compounds of Baru laut plants to PfENR shows that beta-sitosterol forms the strongest bond with PfENR compared to the other two compounds, the bond strength is similar to that of artemisinin derivatives. Gossypol forms a stronger bond than linoleic acid but is weaker than beta-sitosterol and artemisinin derivates.

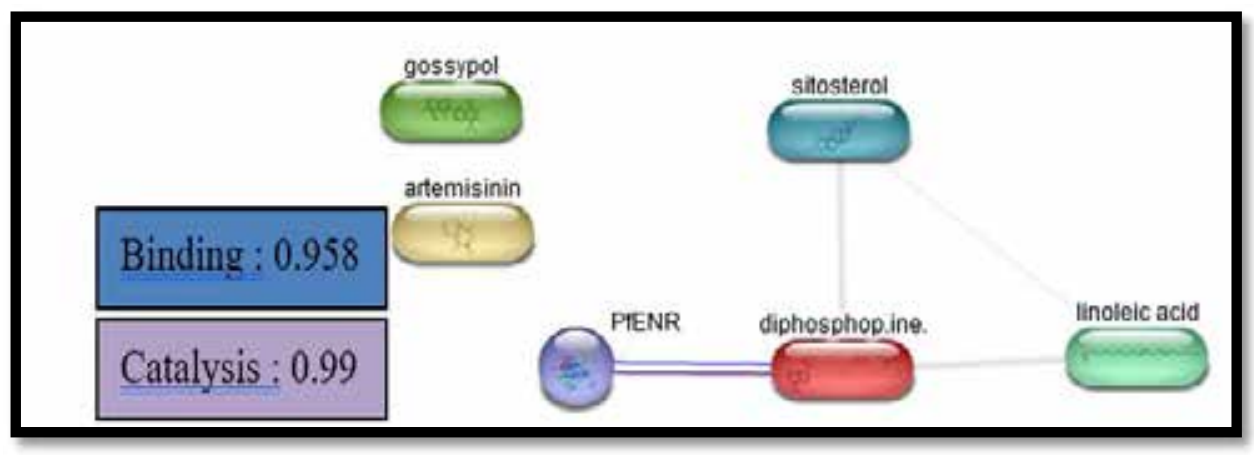

Figure 3. Pathway prediction active compounds of Baru laut plant against PfENR

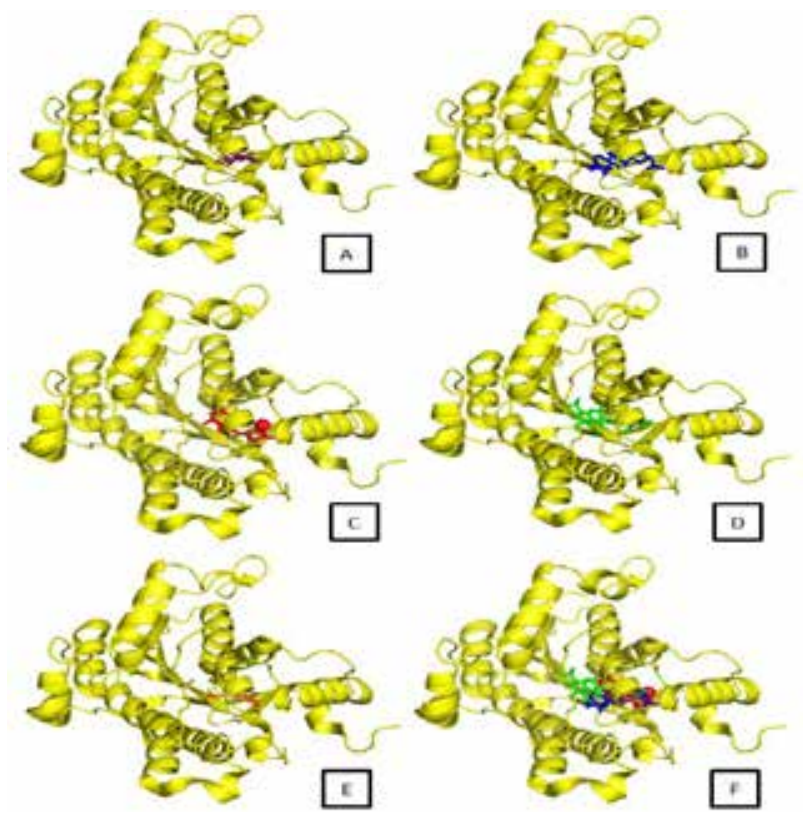

Figure 4. Visualization of molecular docking result between PfENR with a ligand. $\mathrm{A}$ is an Artemisinin bond, B is Beta-sitosterol, C is Control, D is Gossypol, E is Linoleic acid, and $\mathrm{F}$ is the overall result of molecular docking. 


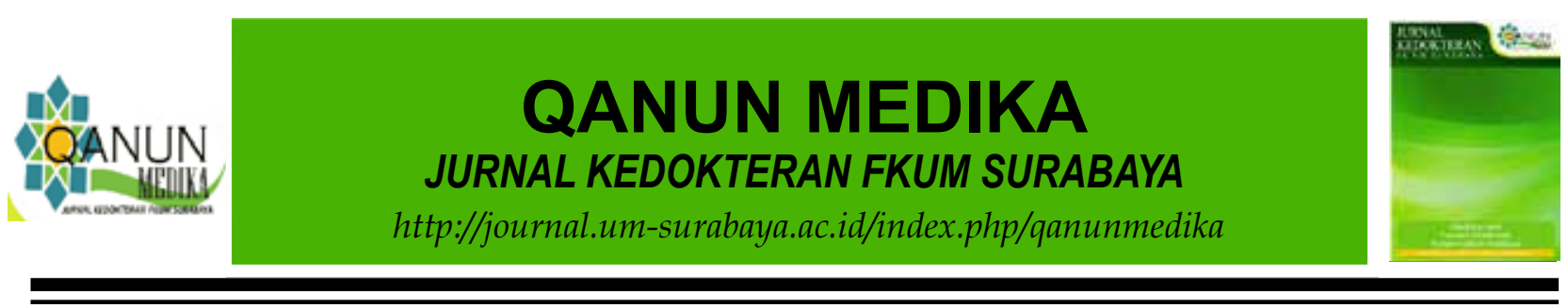

Table 2. Molecular docking results between PfENR and ligand

\begin{tabular}{clcc}
\hline No & Substances & Score Binding Affinity $(\mathbf{k c a l} / \mathbf{m o l})$ & Color visualization \\
\hline 1 & Beta-sitosterol & -9.9 & Blue \\
2 & Gossypol & -6.9 & Green \\
3 & Linoleic-acid & -6.3 & Orange \\
4 & Artemisinin & -9.9 & Purple \\
5 & Control & -8.8 & Red \\
\hline
\end{tabular}

Table 3. Visualization of LigPlot results between PfENR and ligand. Thickened data is the same amino acid residue between Control and Comparative Ligands.

\begin{tabular}{|c|c|c|}
\hline Substance & Hydrophobic Bond & Hydrogen Bond \\
\hline Control & $\begin{array}{l}\text { GLY110 SER317 ALA312 PRO314 TYR277 } \\
\text { TYR267 PHE368 ILE369 ALA217 ALA319 }\end{array}$ & TYR111 GLY313 \\
\hline Beta-sitosterol & $\begin{array}{lllll}\text { ALA320 } & \text { GLY313 } & \text { LYS285 } & \text { TYR111 } & \text { THR266 } \\
\text { ALA217 } & \text { MET281 } & \text { ASN218 } & \text { ALA319 } & \text { ILE323 } \\
\text { VAL222 } & \text { TYR277 } & \text { ILE369 } & \text { PHE368 } & \text { TYR267 } \\
\text { PRO314 } & \text { LEU315 } & & & \end{array}$ & \\
\hline Gossypol & 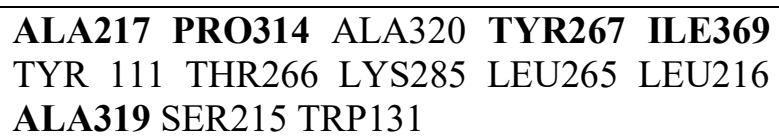 & $\begin{array}{lr}\text { ASN 218 } & \text { SER317 } \\
\text { LEU315 } & \text { GLY313 } \\
\text { ALA312 } & \end{array}$ \\
\hline Artemisinin & $\begin{array}{l}\text { ILE369 } \text { ALA320 PRO314 GLY313 TYR267 } \\
\text { ALA312 LEU265 TYR111 THR266 ILE323 }\end{array}$ & TYR277 LYS285 \\
\hline Linoleic-acid & $\begin{array}{l}\text { ALA312 THR266 SER215 SER317 GLY313 } \\
\text { TYR111 ILE323 PHE368 TYR277 ALA320 } \\
\text { ILE369 TYR267 }\end{array}$ & $\begin{array}{l}\text { LEU265 } \\
\text { LYS285 }\end{array}$ \\
\hline
\end{tabular}

\section{Prediction of Absorption, Distribution, Metabolism, Excretion (ADME) and Toxicity.}

The prediction of ADME using the ADME SWISS web server (http://www.swissadme. ch/index.php) is reviewed using the Lipinski parameter. The prediction of toxicity using Pro-Tox (http://tox.charite.de/protox_II/) by using toxic dose or LD50 parameters with values in $\mathrm{mg} / \mathrm{kg}$ body weight and toxicity class according to the chemical labeling classification system that is globally harmonized system (GHS). The results of these predictions can be seen in the Table 4 .

Based on the results of ADME predictions made, it can be seen that beta-sitosterol, linoleic acid, and artemisinin have passed the Lipinski parameter. At the same time, gossypol does not pass because it has violated 2 of the three provisions, namely the weight exceeds 500 Dalton and also hydrogen bond donors that exceed 5. Among the compounds from Baru laut plants tested, linoleic-acid is the best compound because it has sufficient water solubility, high GI absorption, and high bioavailability. It indicates that linoleic acid is the closest to artemisinin derivatives. Then the results of the toxicity prediction can be seen in the Table 5.

Based on the results of the prediction of toxicity that has been done, it can be seen that linoleic acid has the highest Lethal Dose (LD50) value that exceeds artemisinin which is $10,000 \mathrm{mg} / \mathrm{kg}$ $\mathrm{BW}$, which is included in class 6 (this class is the safest class for consumption). 
Table 4. Prediction of ADME results between $P f E N R$ with ligands

\begin{tabular}{lcccc}
\hline \multicolumn{1}{c}{ Explanation } & Beta-sitosterol & Gossypol & Linoleic-acid & Artemisinin \\
\hline Molecular Weight & $414.71 \mathrm{~g} / \mathrm{mol}$ & $518.55 \mathrm{~g} / \mathrm{mol}$ & $280.45 \mathrm{~g} / \mathrm{mol}$ & $282.33 \mathrm{~g} / \mathrm{mol}$ \\
Number of Atom & 30 & 38 & 20 & 20 \\
Hydrogen Bond Acceptors & 1 & 8 & 2 & 5 \\
Hydrogen Bond Donors & 1 & 6 & 1 & 0 \\
Air solubility & Low & Low & adequately & High \\
GI Absorption & Low & Low & High & High \\
Blood-Brain Barrier & - & - & + & + \\
Bioavailability & 0.55 & 0.17 & 0.56 & 0.55 \\
\hline
\end{tabular}

Table 5. Prediction of Toxicity results.

\begin{tabular}{ccccc}
\hline Explanation & Beta-sitosterol & Gossypol & Linoleic-acid & Artemisinin \\
\hline Prediction of LD50 (mg/kg BW) & 890 & 325 & 10.000 & 4.228 \\
Prediction of Toxicity (class) & 4 & 4 & 6 & 5 \\
\hline
\end{tabular}

\section{DISCUSSION}

\section{Prediction of potential compounds Baru laut as antimalarial}

Baru laut plants have various active substances including flavonoids, alkaloids, saponins, tannins, terpenoids, phenolics, gossypol, betasitosterol, and linoleic-acid. The results of the prediction of potentially active compounds that have antimalarial effects indicate that there are 3 active compounds in baru laut plants that have antimalarial potential. The three compounds include gossypol, linoleic acid, and betasitosterol. The prediction of beta-sitosterol's potential test shows that the compound has no antiparasitic activity but has potential as an antimalarial. It is likely due to the active compound does not work as an antiparasitic against protozoa other than Plasmodium and helminths but has the potential as an antimalarial. This is related to a study conducted by Bo Zhai showing that the Bixa Orelanna $L$ plant contains beta-sitosterol, which has the potential to be an antimalarial in linoleic acid shows that the compound has activity as an antiparasitic and as an antimalarial (Zhai et al., 2014). This proves that linoleic-acid can work on Plasmodium as an antimalarial and be an antiparasitic addition to Plasmodium such as worms and other protozoa. This is related to a study conducted by Paula Melariri showing that linoleic-acid compounds have potential as an antimalarial (Melariri et al., 2012). Furthermore, the last prediction of potential is gossypol which shows that the compound has no antimalarial activity but has potential as an antiparasitic. This is probably due to the active compound does not work as an antiparasitic to Plasmodium (antimalarial) but only works against other parasites such as worms or can be said to have potential antiparasitic but not as an antimalarial. However, a study conducted by Hoda Keshmiri-Neghab showed that the plant Thespesia populnea (L) Soland ex Correa contains gossypol, which has the potential to be an antimalarial (Keshmiri-Neghab \& Goliaei, 2014). Overall results on the prediction of potential were obtained that Thespesia populnea (L.) Soland ex. Correa has a role as an antiparasitic, especially Plasmodium but the value is not as high as the prediction of artemisinin derivates.

Prediction of the mechanism of action of active compounds against PfENR 


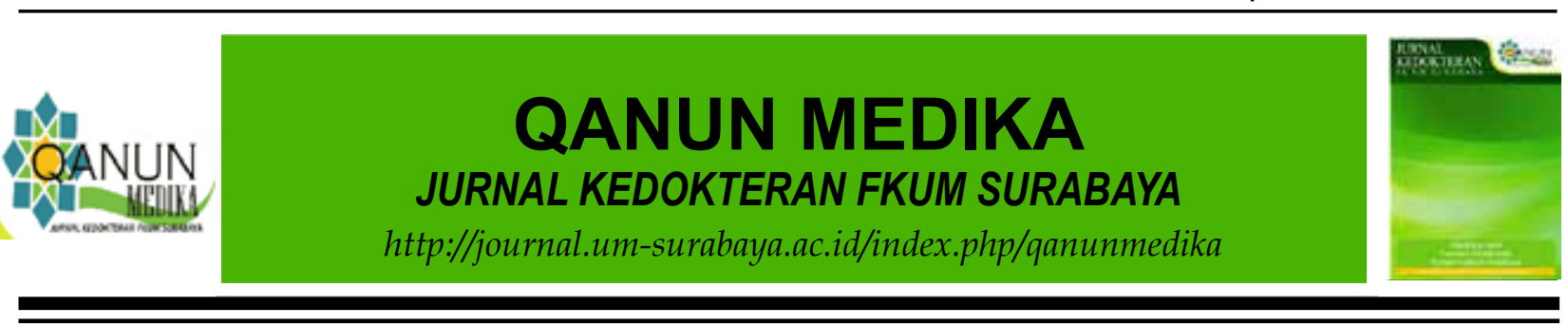

The results of the prediction of the mechanism of action of the active compounds against $P f E N R$ indicate there is an indirect interaction between the active compounds of Baru laut plants, beta-sitosterol, and linoleic acid in diphosphopyridine nucleotide in PfENR. Diphosphopyridine nucleotide or nicotinamide adenine dinucleotide (NAD) components are cofactors that result from crotonoyl-CoA catalysis with NADH cofactors being butyryl$\mathrm{CoA}$ and NAD and are alternating reactions (Zuchrian, 2010). In this experiment, betasitosterol was proven that the compound was able to bind indirectly to PfENR through inhibition of the diphosphopyridine nucleotide component of PfENR. Then linoleic acid is also shown to have an antimalarial effect and even affects an insecticide through diphosphopyridine nucleotide, which is similar to the mechanism of beta-sitosterol (Jansen et al., 2017). Then gossypol and artemisinin, there is no direct or indirect interaction with $P f E N R$. This is because gossypol has a more precise target at $P f L D H$ (Razakantoanina et al., 2000). Whereas artemisinin targets Plasmodium falciparum SERCA-type ATPase 6 receptors(Suwandi, 2015).

After that, the molecular docking method will be continued, with the results of gossypol (-6.9), beta-sitosterol (-9.9), artemisinin (-9.9), and linoleic-acid (-6.3) with control (-8 8). In this experiment, beta-sitosterol has the highest potential compared to other compounds and has the same value as artemisinin. The residue of beta-sitosterol has many similarities with control, even with artemisinin almost entirely the same. Because of this, the binding value of beta-sitosterol is not different from artemisinin and not much different from control (Bintari, 2018).

\section{Prediction of ADME and toxicity}

The next step is predicting absorption, distribution, metabolism, and excretion or
ADME of all compounds. Among all the compounds tested, linoleic acid was the best compound because it passed all Lipinski parameters and had sufficient water solubility, high GI absorption, and high bioavailability. Beta-sitosterol is not good even though it has passed Lipinski parameters and has high bioavailability but has low water solubility and low GI absorption. However, gossypol has violated 2 out of 3 Lipinski parameters, low bioavailability, low GI absorption, and low water solubility, so gossypol can be said to be unsuitable as a drug.

Then in the final experiment, the toxicity test. In this test, linoleic acid has the highest LD50 value of $10,000 \mathrm{mg} / \mathrm{kg}$ body weight classified in class 6 , which is the safest class, even exceeding the value of artemisinin which is only $4,228 \mathrm{mg} /$ $\mathrm{kg}$ bodyweight included in class 5 . At the same time, beta-sitosterol has a value of $890 \mathrm{mg} / \mathrm{kg}$, which is included in class 4 , and continued with gossypol with a value of $325 \mathrm{mg} / \mathrm{kg}$, which is included in class 4 .

From all tests that have been done, all compounds can be used as a drug, but depending on the processing of extracts up to the way of administration of compounds that will be used as alternative drugs. As in vitro research by the Neeraj Sethiya group, it can be proven that gossypol has high inhibitory power in PfLDH. It can be said that gossypol can also be used as a drug even though it has a deficiency in inhibiting PfENR (Sethiya et al., 2014). Whereas beta-sitosterol has also been proven to affect Plasmodium as an antimalarial drug by Anna Caroline C Aguiar, although the target drug mechanism described is not specific (Aguiar et al., 2012). Furthermore, the linoleiclinoleic acid proven by Damtew Bekele that linoleic acid can be used as an antimalarial drug and even has an insecticidal effect, especially to kill mosquitoes which are vectors of the cause of malaria (Bekele et al., 2018). Baru laut plants correlate with antimalarial effects 
against anti-inflammatory because if there is an antimalarial effect, the inflammatory process will be inhibited by inhibiting erythrocyte damage. Inflammation in malaria is caused by high levels of parasitemia which can cause cytokine storms. By suppressing parasites, it is hoped that the reduction of cytokines and inflammation will be suppressed (Ilavarasan et al., 2012).

\section{CONCLUSION}

The prediction of the potential of Baru plant compounds (Thespesia populnea (L.) Soland ex. Correa) proves that it has an antimalarial drug potential. The two active compounds that have antimalarials potential are beta-sitosterol and linoleic-acid. However, their potential is lower than the artemisinin derivate. The prediction of the mechanism of action of active compounds of Baru laut plants, namely betasitosterol and linoleic-acid, showed an indirect barrier to PfENR/Plasmodium falciparum enoyl acyl carrier protein through diphosphopyridine nucleotide. Beta-sitosterol compounds have a higher binding affinity than other compounds, and the size of the binding affinity resembles that of artemisinin derivatives. The ADME prediction proves that linoleic acid has the best ADME ability to nearly matching artemisinin derivates because it has sufficient water solubility, high GI absorption, and high bioavailability.

\section{REFERENCES}

Aguiar, A. C. C., da Rocha, E. M. M., de Souza, N. B., França, T. C. C., \& Krettli, A. U. (2012). New approaches in antimalarial drug discovery and development - A Review. Memorias Do Instituto Oswaldo Cruz, 107(7), 831-845. https://doi. org/10.1590/S0074-02762012000700001

Bekele, D., Tekie, H., Asfaw, Z., \& Petros, B. (2018). The Biomosquitocides Oreosyce africana (Cucurbitaceae) in the Control of Malaria Vector, Anopheles arabiensis. Biochemistry \& Analytical Biochemistry, 5(3), 2-21. https://doi.org/10.4172/21611009.1000294

Bintari, Y. R. (2018). Studi In Silico Potensi Ekstrak Lipida Tetraselmis Chuii sebagai Antioksidan. 2, 76-81.

Daina, A., Michielin, O., \& Zoete, V. (2017). SwissADME: A free web tool to evaluate pharmacokinetics, drug-likeness and medicinal chemistry friendliness of small molecules. Scientific Reports, 7(January), 1-13. https://doi.org/10.1038/srep42717

Fallis, A. . (2013). Uji Sitotoksik, Toksisitas, dan Prediksi Sifat Fisikokimia Senyawa Isoliquiritigenin dan Oxyresveratrol Terhadap Reseptor B-Sel Lymphoma 2 (4AQ3) dan Vaskular Endotelia Growth Factor Reseptor-2 (2RL5) Sebagai Terapi Kanker Servic Secara In Silico. Journal of Chemical Information and Modeling, 53(9), 1689-1699. https://doi. org/10.1017/CBO9781107415324.004

Filimonov, D. A., Lagunin, A. A., Gloriozova, T. A., Rudik, A. V., Druzhilovskii, D. S., Pogodin, P. V., \& Poroikov, V. V. (2014). Prediction of the biological activity spectra of organic compounds using the pass online web resource. Chemistry of Heterocyclic Compounds, 50(3), 444457. https://doi.org/10.1007/s10593-0141496-1

Fitriah, A. (2017). Analisis Interaksi Senyawa Flavonoid Sukun (Artocarpus altilis) Terhadap Reseptor Estrogen Alfa (Era) Secara In Silico Sebagai Model Kandidat Antikanker Payudara.

Fitriany, J., \& Sabiq, A. (2015). Malaria. Malaria Journal, 4(1), 10-31. https://doi. org/10.18860/al.v0i0.2293 


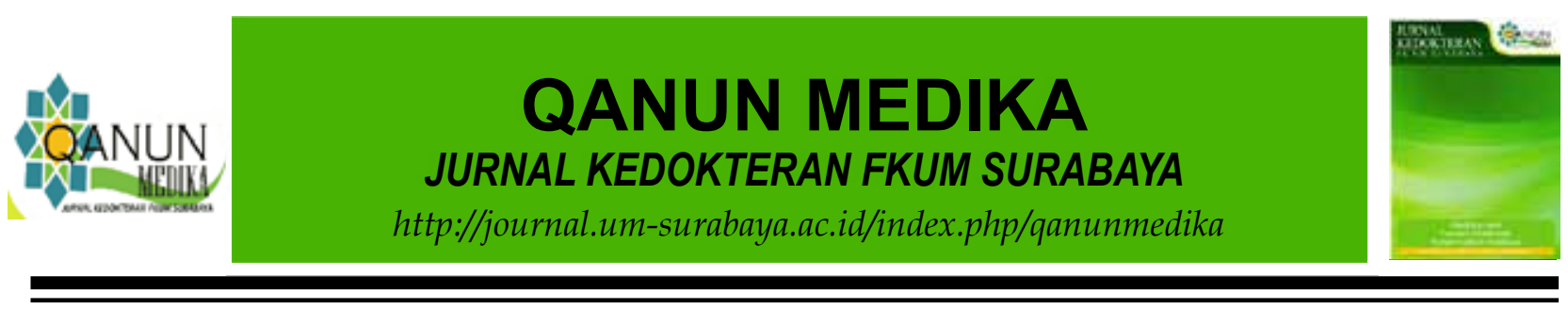

Ilavarasan, R., Mohideen, S., \& Venkataraman, S. (2012). Analgesic and antiinflammatory properties of Thespesia populnea leaf extracts. Natural Product Research, 26(17), 1616-1620. https:// doi.org/10.1080/14786419.2011.574134

Jansen, O., Tchinda, A. T., Loua, J., Esters, V., Cieckiewicz, E., Ledoux, A., Toukam, P. D., Angenot, L., Tits, M., Balde, A. M., \& Frédérich, M. (2017). Antiplasmodial activity of Mezoneuron benthamianum leaves and identification of its active constituents. Journal of Ethnopharmacology, 203(March), 20-26. https://doi.org/10.1016/j. jep.2017.03.021

Kementerian Kesehatan RI. (2016). InfoDatinMalaria-2016.pdf.

Keshmiri-Neghab, H., \& Goliaei, B. (2014). Therapeutic potential of gossypol: An overview. Pharmaceutical Biology, 52(1), 124-128. https://doi.org/10.3109/ 13880209.2013 .832776
Kesuma, D., Siswandono, S., Purwanto, B. T., \& Hardjono, S. (2018). Uji in silico Aktivitas Sitotoksik dan Toksisitas Senyawa Turunan N-(Benzoil)-N'- feniltiourea Sebagai Calon Obat Antikanker. JPSCR : Journal of Pharmaceutical Science and Clinical Research, 3(1), 1. https://doi. org/10.20961/jpscr.v3i1.16266

Melariri, P., Campbell, W., Etusim, P., \& Smith, P. (2012). In Vitro and in Vivo Antimalarial Activity of Linolenic and Linoleic Acids and their Methyl Esters. Advanced Studies in Biology, 4(7), 333-349.

Putra, T. R. I. (2018). Malaria dan Permasalahannya Teuku. FASEB Journal. Conference: Experimental Biology, 32(1 Supplement 1), 103-114. https://www. fasebj.org/doi/10.1096/fasebj.2018.32.1 supplement.819.17\%0 Ahttp:// ovidsp.ovid.com/ovidweb. 